\title{
Homosexuality:
}

\section{A challenge to African churches}

\author{
Maake Masango \\ Department of Practical Theology \\ University of Pretoria
}

\begin{abstract}
Globalization has brought numerous challenges to churches. Homosexuality is one of those challenges facing African churches. There has been a growing evidence of rejection, isolation, discrimination and condemnation as sub-human of homosexuals. Some conservative churches have misused Scripture in order to strengthen their case of condemnation. This article seeks to correct the misinterpretation or misuse of Scriptural passages. For example, Sodom and Gomorrah is often referred to as a passage of Scripture to justify condemnation, while this passage actually deals with judgment. Finally, the article challenges churches to use a pastoral approach which should lead to a healing ministering, especially to all of those who are isolated and rejected.
\end{abstract}

\section{INTRODUCTION}

The Church in Africa is going through a process of purification, brought about by the new challenges posed by globalization. The world has shifted its values in order to be more accommodating of societal changes, while the church struggles to keep up with new developments that seek to address poverty, promote justice, cultivate prospects for peace, and seeks to contribute in faithful ways to what seems to be the formation of a new global society; which will undoubtedly include those committed to other religious traditions.

The issue of gay and lesbianism is particularly problematic for the church in Africa and poses a significant challenge to African churches, "while the Western World has been dealing with these issues". In Africa, homosexuality is hardly ever spoken of. The church pretends it does not exist. When raised though, the church denounces 
homosexuality and condemns homosexuals. In the process, churches have adopted a practice of misquoting Scripture in order to close debate or discussion on the issue of homosexuality.

It has become increasingly important to examine this issue, in light of reactionary attitudes which still prevail in African society. In recent times, for example, two African presidents publicly spoke in the strongest terms possible against homosexuals, following demonstrations of gays and lesbians in their countries. To illustrate the point, I want quote from radio broadcasts of these speeches: "Homosexuals are below the level of a pig, we will not tolerate men who have lost their sexuality" (Radio 702, 10 October 1999, 11:15 am), and "No man is going to be allowed to loose his identity. If they do, we shall lock them up. If they don't understand, we may even castrate them, if it is necessary" (Radio 702, 16 September 2001). The issue becomes further complicated by the fact that the political leaders are supported in these views by some church leaders. Such understandings complicate an already complex discussion. In view of these reactionary speeches, the writer has to ask the following questions: When does a person loose his or her image and likeness of God? What is the role of the church in times like these, in the midst of conflict and humiliation of human dignity? What is our pastoral responsibility to people who have a different sexual orientation?

On 29 September 2001, a rally of gays and lesbians was held in Johannesburg. That day, young men and women came out of the closet and challenged African churches. Archbishop D M Tutu responded to this challenge by offering an apology to the gay and lesbian community for the way in which the church has treated them. $\mathrm{He}$ namely said: "I know that the church has treated you badly, even though the Constitution of the country protects you. I apologise on behalf of the churches" (Radio 702, Oct 2, 2001).

In view of the aforegoing introduction and in the realisation that the current struggle in the church is rooted in the use and interpretation of Scripture, I consider it necessary to revisit the Scriptures. In the Black church there is a tendency to close arguments on the subject of homosexuality by criticising homosexuals and by misquoting Scripture. Fundamentalists also coin phrases and misquote certain passages of Scriptures, in their attempts to condemn homosexuals. No more divisive an issue faces the churches 
in Africa today than the question of homosexuality, with the underlying issue of the misquoting of scriptural passages in order to condemn it. Like the issue of slavery, which the American churches had to face a century ago, this issue has the potential to cause enormous pain in the church, and as was the case with the slavery debate, the argument again revolves around the misinterpretation of Scripture.

In this article, I will attempt to explore certain passages of Scriptures which are frequently used to condemn the practice of homosexuality. The aim is to search for the truth, especially in those passages of the Scriptures alluding to homosexuality. Secondly, I will explore the way in which the church has treated homosexuals, as I pose the very pertinent question which the African Churches must face in this new millenium, namely: "What would Jesus do?"

Finally, I will conclude by presenting a possible pastoral response to the issue of homosexuality. The question that troubles my soul is, how can we minister to people who some regard as sub-human? In order to respond to this question, we (the church) need to start our ministry from an informed position, which implies knowledge of our textbook (the Bible). It should also be borne in mind that the church has always taken a condemning stance and we thus must ask ourselves what does forgiveness mean in this instance. I want to journey with you through the biblical understanding of scriptural passages regarding homosexuality. Unfortunately, we have taken different positions in interpreting the Scriptures. As the African Church, we need to set Christian values that will guide people, in order to relate to each other in the spirit of Ubuntu (human dignity).

\section{UNDERSTANDING HOMOSEXUALITY}

Homosexuality is defined as the orientation of sexual need, desire, or responsiveness towards other persons of the same gender. However, this desire is not openly expressed (in conservative communities) because of the fear of rejection, isolation, and even the fear of being victimised. If the person is consciously aware of the desire, this desire (in conservature circles) may be frustrated, sublimated or actualised especially if it is actualised as a pattern of sexual behaviour - hence people involved will rigorously hide it from others. According to Callahan (2001:210), homosexual desire or behaviour may be exclusive or may co-exist in varying degrees with heterosexual desire and behaviour. In 
this paper, the terms "homosexual", "gay" and "lesbian" are applied only to persons whose conscious sexual desire, and experience are exclusively or primarily directed towards other persons of the same sex. Homosexual orientation will designate the presence of a conscious primary sexual preference for persons of the same sex, whether or not this is actualised in overt sexual behaviour. However, the church has a major problem with such behaviour or desire, insofar as the church regards it as a deviation from the way in which humans were created. "Hence the church has a big problem with this kind of behaviour or desire." The official teaching of the church is well captured by Nilson when he states that: "Homosexuality constitute a deviation from the order of nature according to which humans are created male and female by God; moral norms based on the truth of human nature are unchangeable since 'human nature' is complete and finished" (Nilson 2001:61).

The viewpoint that sexuality is complementary, cannot be disputed. Therefore, the two dimensions of sexual activity, unitive and procreative, may not be "unnaturally" separated. Homosexuals may argue that they also experience pleasure in this area. The church's response to this argument is that the giving and receiving of sexual pleasure by homosexual persons, whether lovingly and permanently committed to one another, is not the issue. The issue at stake is that the practice is contrary to the divine will. The church will never change its stance on the matter and will continue to teach the above norms. Given the above argument, it is understandable that homosexuals are afraid to disclose their status. The reader will now understand what is at stake and why the debate on the topic has become so important. The African Churches are challenged to respond to this contentious issue. We can no longer pretend that it does not exist. The church will not solve this problem by chasing homosexuals out of churches. This stance add more confusion to the role of the church, a church that used to minister to people. We are called to minister to God's children.

\section{THE BIBLE AND HOMOSEXUALITY}

An underlying tendency in the churches' stand on homosexuality, is that of misinterpreting Scriptures in order to condemn the practice of homosexuality. The African Church, especially the conservative churches, should exercise caution when 
using Scripture to state their position on this issue. Cognisance should be taken of the fact that the Bible says remarkably little about homosexuality - in fact, there is no Biblical word for homosexuality or for homosexual. Relevant texts tend to speak graphically about actions, not about persons or sexual orientation. Some of the Biblical passages regularly invoked in debates refer indirectly to the actions of homosexuality. For example, the well known passage in Genesis 19 on Sodom and Gomorrah, and the lesser known parallel account in Judges 19, dealing with Gibeah, deal with issues such as gang rape, violence, and the flagrant disregard for the sacred obligation to provide hospitality. The depravity of the characters in these two accounts is not equivalent to homosexuality. The African church needs to take note of how these passages of Scriptures are misinterpreted. We know from subsequent Biblical texts that Sodom and Gomorrah became symbolic of God's judgment, and not of homosexuality. Several passages of Scriptures illustrate the point, namely Deuteronomy 29:23, Jeremiah 23:14, 49:18 and 50:40. The prophet Ezekiel adds to our understanding of the Sodom and Gomorrah symbolism and I quote: "This was the guilt of your sister Sodom; she and her daughters had pride, excess of food and prosperous ease, but did not aid the poor and needy" (Ezek 16:49).

References to Sodom and Gomorrah as symbol of God's judgment, also appear in the New Testament and passages such as the following are relevant in this regard: Matthew 10:15; 11:23-24; Mark 6:11; 17:29; Romans 9:29; 2 Peter 2:6; Jude 1:7; Revelations 11:8. In all these instances homosexuality features insofar as it is sinful, and as such it leads to judgment.

\section{THE HOLINESS CODE OF ISRAEL}

When dealing with Biblical reference to homosexuality, it needs to be borne in mind that very few passages of Scriptures deal with homosexuality. As a church, we should avoid using passages dealing with violation, in an effort to condemn homosexuality. Leviticus, however contains two texts which are indeed pertinent to the topic of homosexuality, namely: "You shall not lie with a male as with a woman, it is an abomination (Lev 18:22) and "If a man lies with a male as with a woman, both of them have committed abomination; they shall be put to death, their blood is upon them" (Lev 20:13). 
Both the above texts form part of the holiness code of Israel, which formulates guidelines for an appropriate lifestyle for the Israelites, who lived among foreign people with strange religious structures, so as to distinguish them from their neighbours. As such, they define patterns of behaviour to regulate the life of the Israelites and their religious cult and the code could therefore be regarded as a confession of faith. Given the historical setting and purpose of the holiness code of which the aforementioned texts form part, a rigid law developed to guide the Israelites. Paul, however reminds us (and them) that not only does the law, but grace also apply. This leads us to consider the issue of sin in human nature, which needs to be addressed from a perspective of forgiveness. In dealing with the sinfulness of human nature, other sins and sinful issues, which merit similar treatment need to be considered along with homosexuality, in order to get a balanced perspective of this issue. The African Church tends to emphasize one kind of sin above others. With this in mind Western puritans taught us how to separate degrees of sinfulness. Let us be reminded though, that Lev 11 lists other prohibitions as well, such as prohibiting the eating of rare meat, incest, bestiality, stealing, lying and cheating, the wearing of clothes made of two different materials, and the wearing of tattoos, among other things. Clearly, the holiness code contains a combination of purity regulations and moral prescriptions. The church, through the Holy Spirit has elected to preserve some of these prescriptions and to discard others. Having dealt with certain Old Testament insights, let us subsequently analyse some passages of Scriptures in the New Testament, which will help clarify the issue of homosexuality.

\section{NEW TESTAMENT}

Three passages of Scripture from the New Testament warrant consideration, namely Romans, Corinthians and Timothy, with the following being highlighted:

For this reason God gave them up to degrading passions. Their women exchanged natural intercourse for unnatural (Rm 1:26).

[A]nd women were consumed with passion for one another. Men committed shameless acts with men and received in their own persons the due penalty for their error (Rm 1:27). 


\section{Homosexuality: A challenge to African churches}

Do you not know that wrongdoers will not inherit the Kingdom of God? do not be deceived! Fornicators, idolaters, adulterers, male prostitutes, sodomites ... (1 Cor 6:9)

Fornicators, Sodomites, slave traders, liars, perjurers, and whatever else is contrary to the sound teaching ... (1 Tm 1:10).

Now let us analyse the above passages of Scriptures. Because of the similar language, and similar function in the context of 1 Corinthions 6:9 and 1 Timothy 1:10, and in view of the distinct weighty nature of Romans 1:26-27, I shall deal with 1 Corinthians and 1 Timothy together, before focusing on Romans.

\section{Corinthians 6:9-11}

Paul chides the Corinthians for their spiritual arrogance which led to their failure to address immorality and inter-church disputes in a responsible fashion. In exhorting the Corinthians to faithful action, Paul contrasts their present quality of life in Christ with their past unrighteousness. To make his point, Paul catalogues in stereotypical fashion, the previous unrighteous characteristics of the now justified Corinthians. He describes those who belong to this world, not those who are in the Kingdom of God. He says to the Corinthians "Do not be deceived, fornicators, idolaters, adulterers, male prostitutes, Sodomites, thieves, the greedy, drunkards, revilers, robbers ..." (1 Cor 6:9, 10). Paul states that those guilty of such acts will not inherit the Kingdom of God and that indeed was what some of the Corinthans were doing. He challenges the Corinthians on moral issues which have moved them away from Christian values.

Next, I wish to examine the word "male prostitutes" which appears in 1 Corinthians 69 , and which is relevant to the topic of this paper. The word translated in the NRSV as "male prostitutes" in Greek, literally means "soft ones", probably referring to the so-called passive partner in homosexual activity. It is is important for fundamentalists and Pentecostal Churches to realise that one needs to understand the translation of an original text, before one can make certain assumptions about it. This poses a challenge for African Churches too. Furthermore, the Greek word translated as "Sodomites", literally means "male bedders", which could be referring to the "other" 
partner in a homosexual arrangement. In the context of a return to original meanings, Boswell explores the issue of homosexuality. He shares the opinion that the deeper meanings of words like "male prostitutes" and "Sodomites" help us in being faithful to the Scriptures. When dealing with homosexuals, (he suggests) one needs to separate their sins from whom they are, and then one should address their humanity, especially the "image and likeness of God" (Boswell 1994:39). Such an approach will eventually lead them to establish for themselves, whether they have lost the image and likeness of God. Boswell focuses on an approach of love which avoids judging homosexuals, because judgment is in the hands of God. He also believes that judgment causes homosexuals to end their relationship with one, as they will reject you because they feel isolated. The strategy of ministry or pastoral care should be to love homosexuals for the sake of the Kingdom of God. Then one would finally be invited to journey with them as they deal with their sin.

Scroggs announces of Paul's letter to the Corinthians, focuses on an idiom deriving from the Septaugint 1 Version (of Leviticus), "And you shall not sleep in bed with a man as with a woman" (1 Cor 6:9), follows the Leviticus passage "And whoever may lie in bed with a man as with a woman, both of them committed an abomination, they shall be put to death, their blood is upon them" (Lev 20:3). Thus, Paul's condemnation of homosexual acts presupposes the holiness code of Leviticus. Similarly, in 1 Timothy 9, arguing for the value of the law, that is the legal portions of the Jewish Scriptures for "the lawless and disobedient". Verse 10 contains a list of who are considered as lawless and disobedient. Again, the list includes "male bedders", apparently assuming/referring to sections of Leviticus, namely. "You shall not lie with a male as with a woman, it is an abomination" (Lev 18:22) or "If a man lies with a male as with a woman, both of them have committed an abomination' they shall be put to death, their blood is upon them" (Lev 20:13).

The two quotations are repeated in the I Corinthians 6:9. The author of this letter deals with concrete problems in the life of the church, which included homosexuality as one of the activities to be dealt with as such action or behaviour was unacceptable. The African Church should exercise caution not to single out the act of homosexuality from 


\section{Homosexuality: A challenge to African churches}

the other sins also mentioned in the above passages. Sin is sin and needs to be dealt with, irrespective of whether it is homosexuality, corruption, fornication, et cetera.

\section{PAUL'S THEOLOGY}

It is also important to analyse Paul's theology so that we may understand his way of dealing with sin. Paul's way of life was to deal with sin. He enters into the life of Christ as a sinner, as one who persecuted christians, in other words as sinful person. Given his inclination to deal with sin, one would understand why he takes a hard line with regard to homosexual activities when in Romans 1:26 and 27 he says:

Because of this, God gave them over to shameful lusts. Even their women exchange natural relations for unnatural ones (Rm 1:26).

In the same way the men also abandoned natural relations with women, and were inflamed with lust for one another. Men committed indecent acts with other men, and received in themselves the due penalty for their error ( $\mathrm{Rm}$ $1: 27)$.

This brings us closer to the real issue of homosexuality - which is that of shameful and indecent acts and Paul challenges these acts by both men and women..

This passage is mentioned in the course of serious and significant theological reflection. It should also be noted that Paul was addressing both Jews and Greeks, reminding them that the righteousness of God is revealed through faith. Paul reminds us that "the one who is righteous will live by faith." He then carefully crafts an argument designed to make the point stated in Romans 3:9: "What then? are we any better off? Not at all, for we have already charged that all, both Jews and Greeks, are under the power of sin." This point is reiterated in verse 23 in the same chapter: "since all have sinned and fall short of the glory of God" (Rm 3:23).

Here, Paul's chief concern is to declare God's righteousness, that means to declare the salvation of all humankind, as God works to save sinners who may be seen otherwise as sinful humanity. In his attempt to do so, he involves both Jew and Gentile. In order to make the Roman reader realise how great a work God's salvation is, Paul 
discusses the hopeless sinful condition of humanity, when in Romans 1:18-32, he directs his attention towards the Gentiles by focusing on their fundamental sin, namely idolatry.

Then, having declared the failure of the Gentiles to acknowledge and honour God, Paul turns towards the Jews and declares them equally guilty, because they trusted and revered the law, rather than God. Therefore, both Gentiles and Jews have ignored the one true God, as they trusted idols or the law and their own human devices instead. In ignoring God and trusting something less than God, both Jew and Gentile, as well as all of humanity, have sinned against God. We all need "Grace" - those who condemn, as well as those who are being judged as sinful.

Thus, we need to discuss homosexuality within the context of the theology of sin. This understanding will bring us to a deeper appreciation of human relationships. We cannot separate homosexuality from other sins, which is the problem that African Churches are struggling with at the moment. One can understand why Paul refers to the irony of homosexual behaviour as a clear symptom of sinfulness. Since homosexuals come under the power of sin, they are isolated from relating to God because of sin. This Richard elaborates on the widely accepted theological approach to the realm of human sexuality, which deals with the concept of the order of creation in the following quotation:

Paul singles out homosexual intercourse for special attention because, he regards it as providing a particular graphic image of the way in which human fallenness distorts God's created order. He continues to say that God the creator, made man and woman for each other, to cleave together, to be fruitful and multiply. When human beings engage in homosexual activity, they enact an outward and visible sign of an inward and spiritual reality; the rejection of the Creator's design. They embody the spiritual condition of those who have "exchanged the truth about God for a lie.

(Jung 2001:119)

Other writers regard homosexual acts as instrinsically evil acts. While I do not think that sexuality can be separated from its place in the ordering of creation, I have encountered two reservations about theological reflection which lean too exclusively on this approach. 
One is the fact that the church, in its reflection of God's work of ordering creation, has often been tempted to see its task in dealing with sexuality as one of ordering, also. In the African Church, the emphasis thus becomes one of restraint, prohibition, legism, and the definition of limits. Yes, all of the above may be necessary, but it does not respond to the equally Christian calling to glorify God by the joyful celebration of and delight of our sexuality. The attempts by some theologians to encourage Christians to appreciate the fact that our sexuality is not only functional, but can be fun as well, have thrown some of our fellow faithfuls into paroxysms of fear and guilt. The second reservation concerns the fact that marriage and the family is regarded as the exclusive model for ordering all sexual activity. The emphasis of such an approach is on the pro-creative leading to childbearing and nature. It is important to share the moral norms which govern our lives through Scriptures, but we should guard against communicating a silent message which leaves the impression that the single state is a deficient one, which requires explanation and apology rather than guidance. So, less by intent than by omission, we (Protestants) have left the unmarried in the shadow of an ethical structure designed to serve another manner of life than theirs.

You need to understand why as the African church we need to know how God is speaking to us in our times about sexual relationships. Theology is a dynamic science capable of new insights and interpretation relative to changing culture. Paul, when faced with the issue of homosexuality, responded to it as follows in the letter to the Romans: "Because they exchanged the truth about God for a lie, and worshipped and served the creature rather than the creator .... [F]or this reason God gave them up to degrading passions .... [T]hey received in their own persons the due penalty for their error." Romans 1:27. According to Paul, homosexual activity is not a sin that provokes the wrath of God, rather, the wrath of God comes on humans who are under the power of sin. A sign of both God's wrath and human sin is that humans engage in homosexual acts.

We are also challenged to deal with this issue. The time has come for us to stop avoiding the issue, to stop singling it out as the only sin that we have to deal with and lastly to stop avoiding the misinterpreting of Scripture. 


\section{CONCLUSION}

In conclusion, I wish to highlight two different opinions which are suggested by scholars. One approach to this passage attempts to tone down the negative assessment of homosexuality. The scholars subscribing to this approach suggest that Paul is not denouncing those who are truly homosexual. Rather, they argue that Paul is referring to licentious heterosexual persons who have engaged in homosexual acts. They argue that the text reads that: "their women exchanged natural intercourse for unnatural" and that the men gave up "natural inter-course with women" and "were consumed with passion for one another." (Rm 1:26.) This passage of Scripture speaks to the problem of homosexual passion, describing it as "dishonourable", as well as to the homosexual behaviour, which is described as "unnatural". By "unnatural" the Scripture does not mean contrary to custom, nor contrary to the preference of a particular person, but rather contrary to that order of universal human sexual nature that God intended in Genesis 1 and 2.

It needs to be noted that Paul is not concerned with individual decisions - he is discussing the sinful guilt of all humans. Moreover, neither Paul nor any other ancient person had a concept of "sexual orientation". For Paul and Jewish thinkers, such as Philo and Josephus and other first century Greaco/Roman moralists such as Seneca, Plutarch and Dio Chrysostom, felt that homosexual acts were exploitative willful actions of unbridled lust. The second school of thought notes that Paul was not concerned with individual decisions - in stead, he is discusing in Romans 1:26 the sinful guilt of all humans. For example, Dio Chrysostom when complaining about the easy availability of female prostitutes had the following to say about them (see Best 1998:212-213):

The man whose appetite is insatiate in such things, when he finds there is no scarcity, no resistance, in this field, will have contempt for the easy conquest and scorn for a woman's love, as a thing too readily given ... [A]nd will turn his assault against the male quarters, eager to befoul the youth who will very soon be magistrates and judges and generals, believing in them he will find a pleasure difficult and hard to procure. 
I need to emphasize that Paul deals with sinful acts equally. He includes homosexual behaviour in a larger catalogue of sins, which includes pride, greed, jealousy, disobedience to parents and deceit. The reader need to note that homosexual behaviour is no greater a sin and no less a sin than other sins.

As a church we cannot afford to single homosexuality out as the only graphic sin. Those who judge, and that includes the church, must be mindful of Paul's words in the letter to the Romans "Therefore you have no excuse, whoever you are, when you judge others; for in passing judgement on another you condemn yourself, because you, the judge, are doing the very same things" (Rm 2:1.)

In conclusion, (summarizing Paul's main argument); all human beings are under the power of sin and no single sin, nor any one sinner is better off than the other; and that would include the presidents who condemned homosexuality in public. God's grace through the faith of Jesus Christ freely redeems all human kind. This knowledge opens up a new vision of ministry to all of us who have fallen short ofthe glory of God. As the body of Christ, we are reminded that we can win sinners over by loving them. Let me share some findings or outcomes of my research, and then conclude my arguments with a pastoral care proposal.

\section{FINDINGS}

My research has led to the following findings:

- There is a denunciation of homosexual activity in the Levitical Holiness code;

- The new Testament treats homosexuality in the context of a deliberate theological reflection of Romans 1:26-27;

- Paul assesses the sinful condition of all human beings. He works from the beliefs and traditions of his own time to articulate a theological vision of reality by which the Roman readers, and other early Christians are to gain their theological bearings for life;

- God's purposes for humanity as Paul and others knew it from created order, Scripture, word, and sayings of Jesus, was for men and women, male and female, 
to find fulfillment in the complementary sexual union that guaranteed the continuation of God's own creation;

- Paul was not concerned with origin, motivation, or gratifications of homosexual activity. He was more concerned with the blindness of humanity in bondage to $\sin$;

- It is important to note that homosexual acts were outside the boundaries of God's intentions for humanity. Only God can judge, we must correct actions by loving sinners, and hating the sins they commit. That is our pastoral ministry and action in dealing in love with homosexuals;

- Homosexuality was one vivid indication of the real problem of sin, and Paul states bluntly that all human beings are sinners;

- It is important to note that homosexual activity is not consistent with the will of God; it is not so much a sin as evidence of sin, but it is like missing the mark for the will of life, or for the will of God. Hence judgment of God.

\section{PASTORAL RESPONSE}

It is important for the African Church to note that the Biblical teachings and vision of reality tell us about God, the world, and humanity in such a way that we should know how we are to live our lives according to our calling. The Bible gives meaning to life, and guides and directs our living. As Christians, like Paul, we believe in God's righteousness, His judging wrath, but also in His saving grace. I do believe in the above statements and if you the reader also believe that Paul's assessment of the human condition as stated in Romans 1, namely that human beings are powerlessly in bondage of the distorting power of sin, then you and I will not be able to find a persuasive argument that undermines Paul's diagnosis of homosexual activity. In fact, I believe that by refusing to pronounce a biblical opinion on homosexual activity in the world today, the African Church has taken the easy path, not the high road, and has failed to give a definitive message, yet a message of hope to all humanity about God's will. We (the African Church) have failed to engage in the difficult ministry of pastoral care and reconcialiation to which God in Jesus Christ has called us. 
Let me illustrate this by way of example: The way in which many of us react, including the church, reminds me of passengers aboard a bus. As passengers, we are prepared to follow the driver, even if we do know where we are going to. All we do, is to follow. We are afraid to question where we are going. We never utter a word as we travel along. Similarly, in our religious journey, we never call sinful acts to order, or lead people to repentance. We (the African Church), like the false prophets of old, are prepared to utter sweet words to the ears of the hearers. My words may be harsh, but the point of announcing God's judgment is to declare God's self wrought, reconciliation to humanity in Jesus Christ. If we have hope, we will stop the easy way of saying "I am OK, you are OK" or "Live and let live". Does any one of us believe that?

The gospel tells us that God loves us, despite our sinfulness. In John 3:16, we are reminded that "God loved the world so much, that God gave His Son, so that those who believe in Christ may have eternal life." It is therefore our duty (ministry) to love (pastoral care) the sinner (not sin) in such a way that that person may come to know the love of Christ through our warm actions.

The normal way of the church has always been to condemn or judge the sinner in such a way that they would never experience that Love shared for them (and us) from the cross of Calvary. We are called (as pastoral caregivers) to love and to minister to them. This is our pastoral duty as an African Church. Today we are burying lots of young people, victims of AIDS. The tendency is to quickly jump to the conclusion that homosexuals are the only ones dying of AIDS. This is not true, heterosexuals also die of AIDS. We need to challenge God's children to face sinful acts by showing our love to them.

Finally, our pastoral responsibility is to care and to love as the Lord would have done. This, hopefully will help them to examine themselves and will help us also to examine ourselves. Love and caring for people is one way in which human beings can relate to them. It will be theologically inconsistent for the church to reject homosexuals. We are called to share the grace and mercy of God. This is one way of sharing the gospel of Jesus Christ. 


\section{Works consulted}

Bailay, D L 1955. Homosexuality and the Western Christian tradition. New York: Archon Books.

Beach, F (ed) 1977. Human sexuality in four perspective. Baltimore: John Hopkins University Press.

Beiber, I et al 1962. Homosexuality: A psychoanalytical study. New York: Random House.

Brunner, E 1947. The divine imperative. Philadelphia: Westminster Press.

Churchill, W 1967. Homosexual behaviour among males. New York: Hawthorn.

Cone, J H 1973. Church theory and research in motivation, Vol 21. Lincoln Nebraska: University of Nebraska Press.

Conzelmann, H 1975. Corinthians. Philadephia: Fortress. (Hermeneia.)

Doughty D J 1967. Homosexuality and obedience to the Gospel. Church and Society May and June, p 12-23.

Douglas, M 1966. Purity and danger. New York: Frederick A Praeger.

Gutierrez, G 1973. A theology of liberation. Mary Knoll. New York: Orbis.

Hare, F H jnr 1977. The law and the homosexual. Unpublished paper presented at the Presbyterian United for Biblical concerns, Consultation on Homosexuality. Pittsburgh PA January 27, 1977.

Hewlett, SA 1974. Position statement on homosexuality and civil rights. American Journal of Psychiatry 70, 131-477.

Jung, P B \& Coray J A 2001. Sexual diversity and catholicism. Collegeville, MN: The Liturgical Press.

Kinsey A1948. Sexual behaviour in the human male. Philadelphia: W B Saunders.

Kinsey A 1953. Sexual behaviour in the human female. Philadelphia: W B Saunders.

Loraine, J A 1974. Understanding homosexuality, its biological and psychological bases. New York: American Elsevier.

Nilson J 2001. The Church and homosexuality: A Lonerganian approach. Collegeville, MN: The Liturgual Press.

Risether, R R 1967. The Church against itself. New York: Herder and Herder. 
Russel, L M. 1989. Human liberations in a feminist perspective: A theology. Philadelphia: Westminster.

Harper Study Bible the Holy Bible 1980. Grand Rapid, MI: Sondervan Bible Publishers. 